\section{Omfattende og ujevnt om psykofarmaka}

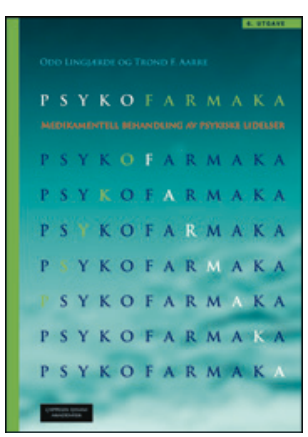

Odd Lingjærde, Trond F. Aarre Psykofarmaka

Medikamentell behandling av psykiske

lidelser. 6. utg. 591 s, tab, ill. Oslo: Cappelen

Damm Akademisk, 2015. Pris NOK 799

ISBN 978-82-02-45386-2

Medisinske sannheter endres fort. Derfor er oppdatering av denne klassikeren, ni år etter forrige utgave, etterlengtet. Målgruppen er psykiatere, allmennpraktiserende leger og andre med interesse for biologisk psykiatri. Denne utgaven har to forfattere, begge svært erfarne psykiatere.

Boken er delt i tre hoveddeler. Den første inneholder bakgrunnskunnskap, som historikk, nevrofysiologi, generelle farmakologiske mekanismer og legemiddelfors $ø$. I del 2 blir de ulike legemiddelgruppene og det enkelte legemidlet beskrevet, mens del 3 tar for seg klassifisering av de psykiske lidelsene og praktisk gjennomføring av behandlingen. For antidepressiver og antipsykotika er nøkkeldata presentert i flere tabeller. Bakerst i boken er det referanseliste, stikkordliste og tabell med alle virkestoffene og preparatnavn.

Denne lettleste boken i muntlig fortellerstil inneholder store mengder fakta og mye interessant lesning. Særlig har delen om behandlingen av psykose og depresjon blitt oppdatert med nye vurderinger og referanser til veiledere, store studier og metaanalyser. Det er lagt til nye legemidler, men siden målet er å omtale alle psykofarmaka som er markedsført i Norge, er det synd at den ikke er oppdatert med de to nyeste (vortioksetin og lurasidon) som fikk markedsføringstillatelse i 2013/14.

Fra et farmakologisk ståsted svekkes boken av flere begreper/ definisjoner som ikke er i tråd med dagens bruk, f.eks. terapeutisk vindu og bivirkninger/komplikasjoner, og som har vært uforandret i hvert fall siden 1988-utgaven. Også omtalen av farmakogenetikk, inkludert CYP-enzymer og interaksjoner, inneholder mange upresisheter og feil. Når det ikke skilles mellom CYP-enzymer som er relevante og mindre relevante for omsetningen av det enkelte legemiddel, drukner viktig informasjon.

Enkelte råd støttes ikke av oppdatert litteratur, som å anbefale gravide å trappe ned antidepressiver før termin for å redusere abstinens hos barnet etter fødselen. Risikoen for forverring hos mor etter fødsel diskuteres ikke og rådet står i kontrast til anbefalingene fra UpToDate og RELIS. Serotoninsyndromet beskrives, men forfatterne bruker en mer uspesifikk og mindre treffsikker definisjon enn den som oftest brukes i dag.

Det er et ambisiøst prosjekt av bare to forfattere å beskrive ikke bare fagfeltet psykiatri, men også farmakologi, farmakogenetikk, rus- og avhengighetsmedisin, studiedesign og teratologi. Innen mitt fagfelt, klinisk farmakologi, er det såpass mange svakheter at boken ikke innfrir mine forventninger.

Sigrid Narum

Seksjonsoverlege, Senter for psykofarmakologi

Diakonhjemmet Sykehus

\section{For lærd og ulærd}

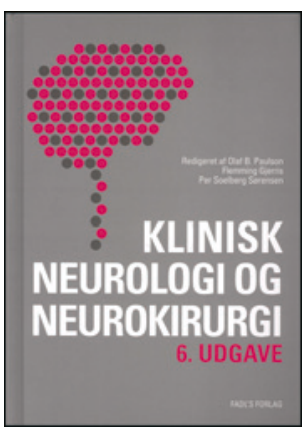

Olaf B. Paulson, Flemming Gjerris,

Per Soelberg Sørensen, red. Klinisk neurologi og neurokirurgi

6. utg. 791 s, tab, ill. København: FADL, 2015 Pris DKK 980

ISBN 978-87-7749-785-8

Dette er sjette utgave av denne læreboken rettet mot medisinstudenter, yngre nevrologer og nevrokirurger. Målet er å gi en god innføring i de vanligste sykdommene som rammer nervesystemet og muskulaturen, i tillegg til å lære opp den gode klinikeren.

Kapitlene er skrevet av forfattere fra ulike fagmiljøer i Danmark, og tre redaktører har sydd dette sammen. Tross mange forfattere fremstår teksten som helhetlig, siden de fleste sykdomskapitlene har relativt lik struktur og oppdeling. Boken er inndelt i 34 kapitler, hvorav de 13 første tar for seg de ulike delene av den nevrologiske undersøkelsen, topografien, akuttnevrologi og de ulike supplerende undersøkelsesmetodene. De øvrige 21 kapitlene omhandler ulike sykdomsgrupper. Alle kapitlene har gode figurer og nyttige tabeller.

Som bonus følger det med et laminert undersøkelseskort med tips om hva den basale nevrologiske journalen bør inneholde. Dette kortet er ment for frakkelommen. Innbindingen kunne vært av bedre kvalitet, da eksemplaret raskt ga etter i limingen.

Språket er gjennomgående godt. Dansk er lett å forstå for en norsk leser. Forfatterne forklarer vanskelige begreper og nevrologiske betegnelser på en pedagogisk måte, og leseren får en god forståelse av faget gjennom de innledende kapitlene.

Noen sykdommer blir nevnt både i de innledende kapitlene som modeller for å forstå den systematiske kliniske undersøkelsen og under sykdomskapitlene. Redaktørene er flinke til å henvise frem og tilbake til ulike kapitler, slik at det ikke blir for mye gjentakelse.

Nevrologiske diagnoser deles inn i grupper avhengig av symptomer, etiologi og topografi. Flere sykdommer blir derfor nevnt i flere sykdomskapitler. At det er laget tabeller over sykdommene i starten av de fleste sykdomskapitlene, gir et godt overblikk og forståelse for hvordan sykdommene henger sammen og overlapper hverandre. I tillegg har de fleste forfatterne i starten av kapitlet en definisjon av sykdommene og lister opp synonymer der det finnes. Redaktørene burde vært konsekvente og gjennomført disse oversiktene i alle sykdomskapitlene.

Forfatterne konsentrerer seg om de hyppigste sykdommene, men kunne med fordel viet større plass til enkelte undergrupper av disse samt sjeldnere diagnoser.

Alt i alt er dette en god lærebok som innfrir både som introduksjonsbok og som en oversikt for den gode kliniker. Læreboken kan på det varmeste anbefales.

\section{Jeanette Koht}

Overlege, Nevrologisk avdeling

Vestre Viken, Drammen 